agency responsible - even the Board of Trade has a hand in scattering resources about the countryside. Thus the letter which appears on page 312 from the director of the Fruit and Vegetable Preservation Research Association is one indication of what can go wrong, although it is also a case where Nature must apologize for having misjudged the Ministry of Technology's part in a badly calculated decision. The facts appear to be these. Some time ago the University of Reading and a number of otherwise independent research organizations-the Tropical Products Institute and the Anti-Locust Research Centre-conceived a plan for concentrating their resources at Reading. The Ministry of Overseas Development seemed to be as glad that its pensioners should make this move as was the Ministry of Technology that the Fruit and Vegetable Preservation Research Association should also move to Reading, for everybody seems to have acknowledged that there would be great advantages in a physical link between these institutions (destined to retain their independence) and what is rapidly emerging as the foremost university in agricultural research in Britain. In the end, however, everybody's hopes were disappointed by the declaration of the Board of Trade that Reading comes within a zone within which industrial development is restricted on planning grounds. The result is that two of the institutions are now busy digging themselves in in Central London. Nobody seems worried that a necessarily arbitrary planning rule has permanently impaired the efficiency of agricultural research in Britain.

This, however, is almost only child's play. The case of the $300 \mathrm{GeV}$ accelerator is a much more striking illustration of how British Governments tend to favour the dispersal of resources, not their concentration. The fact that the proposed $300 \mathrm{GeV}$ machine was intended to be operated internationally by CERN is not, of course, important. What matters is that this was an opportunity for high-energy physicists in Britain to enhance the quality of their operations by joining in a collaborative enterprise in which a greater range of skill and talent could be concentrated. By all appearances, the British Government seems to have failed to recognize the way in which the difference between good science and less good science can sometimes be almost a simple function of the scale of operations. To be sure, there is no universal rule to follow, and there may still be some fields in which the lone and patient worker is not at a disedvantage. But in high-energy physics, as in molecular biology, concentration matters. It is ironical that the people responsible for saying no seem never to have realized the great qualitative benefits which participation could bring. And what if the site had been in Britain ?

The issue of the accelerator is so important that the Government should not be afraid of opening it again. Indeed, it would be prudent to start talking about the project before too much time is lost, for there is no point in accumulating more ill-will than is strictly necessary. To begin with, there would be no harm in asking for a re-examination of the kinds of design proposals which would have been seriously considered at Geneva if the organization planning the accelerator had not been under pressure to stick to its first idea for the sake of solidarity. Not only is there the chance of improvements in design but an opportunity to begin talking again. The Government would also be wise to explore more thoroughly the ways in which the cost of participation in a $300 \mathrm{GeV}$ machine could be offset by reductions of the cost of the strictly national programme which is under way. Evidently the Science Research Council was prepared to go a long way in robbing Peter to pay Paul. The Government could probably strike a good bargain for itself, and win a reputation at the same time, by trying to internationalize the British accelerators already working. To fortify itself, it should also re-examine the report of the economists who advised a year ago that building the machine in Britain would bring no economic advantages - that was dubious even before the devaluation of sterling. But the real need is somehow to escape from the weird belief that, because money is scarce, nothing of any kind is possible. Almost literally, this is a policy of despair.

\section{Porton Revealed}

THE chemical and microbiological research establishments at Porton Down continue to claim the headlines. This week the minutes of evidence taken by the Select Committce on Science and Technology on its visit to Porton were published; the cvidence is still subject to an investigation by the House of Commons Committee on Privileges, after an article appeared in The Observer leaking most of the contents of the evidence.

In the event, the evidence will disappoint those who may have hoped that all the activities at Porton would be made public. Like a Victorian novel, the evidence has a tendency to dissolve at moments of stress into a series of asterisks, hinting at horrors too awful to spell out in full. But the chances are, with existing security arrangements, that the bits missed out are no mo:e significant than those left in. The most significant disclosure was made by $\mathrm{Mr}$ C. E. Gordon Smith, Director of the Microbiological Research Establishment, who was asked by $\mathrm{Mr}$ Arthur Palmer, chairman of the committee, whether, in the event of an attack, Britain would be able to retaliate fairly quickly. "No, sir", Mr Gordon Smith replied, "We should need a good deal of development work before we could retaliate." And Mr Gadsby, Director of the Chemical Defence Experimental Establishment, explained that his establishment did not have the necessary equipment for producing chemical agents on a scale sufficient for military use. This would involve the "whole complex business of chemical engineering". At Nancekuke (an out-station of the establishment) the facilities were available for exploring manufacturing processes, but considerable development would be necessary in order to produce the necessary aerial and ground weapon launching systems.

The evidence also reveals what the two establishments cost to run. The cost of the chemical establishment, which employs seventy scientific and engineering 
grades and 120 experimental officer grades, is $£ 1 \cdot 6$ million per year. The microbiological establishment, with forty-eight scientific officers and seventy-six experimental officers, costs $£ 900,000$ a year. The microbiological establishment has contracts of a non-classified nature with a number of universities, which are listed in the evidence; they are Birkbeck College, University College of South Wales, Oxford University, Oxford College of Technology and Birmingham University. The list of organizations supported by the chemical research establishment is also given, and is much longer, including twenty-seven universities.

Mr Gadsby had some critical things to say about the National Research Development Corporation. The establishment had developed the Porton Portable Resuscitator which, Mr Gadsby said, had already saved several hundreds of lives. The equipment ought to find its way into every fire-fighting service, every ship at sea and so forth, Mr Gadsby added. But his personal impression was that the NRDC had not done sufficient market research or used adequate sales drive.

\section{Night Vision}

Binoculars which make starlight as clear as daylight and $\frac{1}{8}$ inch glass fibre cables which can transmit 20,000 telephone conversations at once are two of the industrial applications to come out of defence work at the Signals Research and Development Establishment at Christchurch, Hampshire, now a dependant of the Ministry of Technology. The SRDE, like many other establishments, is looking for civil applications for previously classified work.

Night vision has occupied the establishment since 1956 but commercial equipment is only now available. One type of image intensifier collects and amplifies residual light from the night sky and can amplify roughly 40,000 times. A similar device has been used for night-sighting by the Americans in Vietnam, with both binoculars and gunsights. Where there is no ambient illumination, however-indoors or in very deep shadows, for example--an active system using an infrared source is now available. Because neither humans nor animals can see light in the near infrared with the unaided eye, a scene can be illuminated by an infrared lamp or even an infrared searchlight. In the hope of turning this sword into a ploughshare, the SRDE is talking about helping police to watch offices or stop pilfering in warehouses. Naturalists may also be tempted to use the devices for studying night behaviour. There is already quite a list of uses like this-monkeys and baboons in Africa, the breeding of vampire bats, and the effect of airfield bird scarers on bird behaviour have all recently been observed. Far infrared devices which are capable of discriminating a difference of one degree centigrade between an object and its background are also now being developed for alarm systems. Changes in temperature cause an increase in voltage which in turn triggers an alarm. The present device has a range of 100 metres and a 5 degree field.

SRDE is a comparative newcomer to optical communications but has not allowed inexperience to temper its optimism. Mr E. Phillips, head of the quantum physics division, suggested last week that within ten years housewives will do their shopping by telephone computer links. This and other developments will mean an increasing demand for more and better communication than the electromagnetic spectrum can provide. Optical frequencies are an obvious solution since the band width is very broad in these high frequency ranges. Laser light sources and glass fibre transmission now seems to be a feasible system though more development work is still needed. Glass fibres 80 microns in diameter are capable of transmitting one television channel or 200 telephone calls simultaneously, and a $\frac{1}{8}$ inch fibre cable contains 200 glass

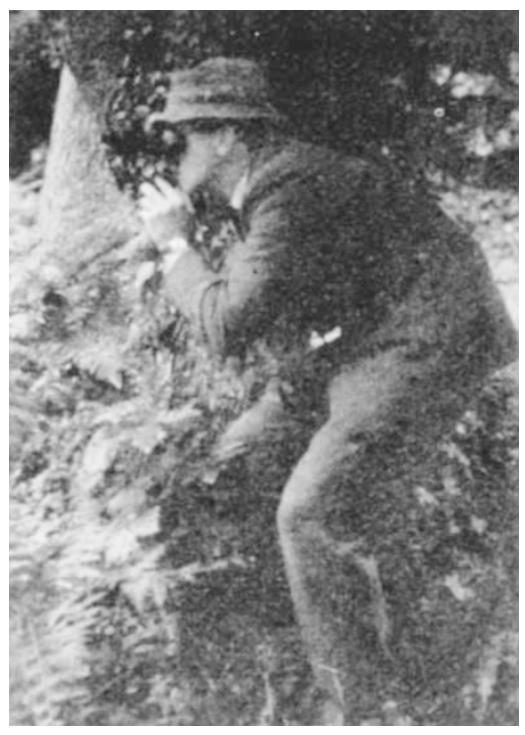

A peaceful user of infrared binoculars.

fibres, but the energy losses in the fibres are still too great. Losses-caused by impurities, particularly iron, in the glass, by light scattering and by the slightly imperfect geometry of the fibre cause the present attenuation level of the glass to exceed $200 \mathrm{db} / \mathrm{km}$, whereas the practical minimum is $70 \mathrm{db} / \mathrm{km}$. A suitable gallium arsenide laser light source has recently been developed which is the same size as a single fibre and operates at room temperature, so the main problems now confronting research workers are the glass fibre losses and the need to improve detector performance.

\section{Research for Education}

THE Organization for Economic Cooperation and Development is setting up a three-year programme to coordinate and encourage educational research in the member countries. The Centre for Educational Research and Innovation will be staffed by the OECD with James R. Gass, the OECD's Deputy Director for Scientific Affairs, as director, but will be financed with a $\$ 1$ million grant from the Ford Foundation.

The centre plans to concentrate on two areas of research-the education of socially deprived children in member countries, and the problem of experimentation and diversification in education, the trends and possibilities of new forms of universities and technical colleges and new educational technology. With work not beginning until September, specific projects have not yet been formulated, but Professor Albert $\mathrm{H}$. Halsey, head of the Department of Social and 